\title{
Mice deficient in MCT8 reveal a mechanism regulating thyroid hormone secretion
}

\author{
Caterina Di Cosmo, ${ }^{1}$ Xiao-Hui Liao, ${ }^{1}$ Alexandra M. Dumitrescu, ${ }^{1}$ Nancy J. Philp, ${ }^{2}$ \\ Roy E. Weiss, ${ }^{1,3}$ and Samuel Refetoff $1,3,4$
}

\begin{abstract}
1Department of Medicine, University of Chicago, Chicago, Illinois, USA. Department of Pathology, Anatomy, and Cell Biology, Thomas Jefferson University, Philadelphia, Pennsylvania, USA. ${ }^{3}$ Department of Pediatrics and ${ }^{4}$ Committee on Genetics, University of Chicago, Chicago, Illinois, USA.
\end{abstract}

\begin{abstract}
The mechanism of thyroid hormone (TH) secretion from the thyroid gland into blood is unknown. Humans and mice deficient in monocarboxylate transporter 8 (MCT8) have low serum thyroxine $\left(\mathrm{T}_{4}\right)$ levels that cannot be fully explained by increased deiodination. Here, we have shown that Mct8 is localized at the basolateral membrane of thyrocytes and that the serum TH concentration is reduced in Mct8-KO mice early after being taken off a treatment that almost completely depleted the thyroid gland of TH. Thyroid glands in Mct8-KO mice contained more non-thyroglobulin-associated $\mathrm{T}_{4}$ and triiodothyronine than did those in wild-type mice, independent of deiodination. In addition, depletion of thyroidal TH content was slower during iodine deficiency. After administration of ${ }^{125} I$, the rate of both its secretion from the thyroid gland and its appearance in the serum as trichloroacetic acid-precipitable radioactivity was greatly reduced in Mct8-KO mice. Similarly, the secretion of $\mathrm{T}_{4}$ induced by injection of thyrotropin was reduced in $M c t 8$-KO in which endogenous TSH and $T_{4}$ were suppressed by administration of triiodothyronine. To our knowledge, this study is the first to demonstrate that Mct8 is involved in the secretion of $\mathrm{TH}$ from the thyroid gland and contributes, in part, to the low serum $\mathrm{T}_{4}$ level observed in MCT8-deficient patients.
\end{abstract}

\section{Introduction}

Over the past few decades, considerable progress has been made in our knowledge of the steps, genes, and mechanisms involved in thyroid hormone (TH) synthesis and its release from the thyroglobulin ( $\mathrm{Tg}$ ) backbone (Figure 1). Iodide, an essential element of the TH molecule, is actively transported by the $\mathrm{Na}^{+} / \mathrm{I}^{-}$symporter (NIS, encoded by the SLC5A5 gene) at the basolateral membrane of the thyrocyte (1) and diffuses by an exchanger, known as pendrin (PDS, encoded by the SLC26A4 gene), to the lumen at the apical membrane (2). At the extracellular apical membrane, thyroperoxidase (TPO) (3), with hydrogen peroxide $\left(\mathrm{H}_{2} \mathrm{O}_{2}\right)$ generated by dual oxidase 2 (DUOX2) (4), oxidizes and binds covalently iodine to tyrosyl residues, producing monoiodotyrosine (MIT) and diiodotyrosine (DIT) within the Tg macromolecule. The same enzyme catalyzes the coupling of two iodotyrosine residues to produce the prohormone thyroxine $\left(\mathrm{T}_{4}\right)$ and smaller amounts of the active hormone triiodothyronine $\left(\mathrm{T}_{3}\right)$. After endocytosis, iodinated $\mathrm{Tg}$ is hydrolyzed in the lysosomes by cathepsins (5) and $\mathrm{TH}$ is released from the Tg backbone. The released MIT and DIT are deiodinated by a specific iodotyrosine deiodinase (IYD, or DEHAL1) (6), and the released iodine is recycled within the cell. However, the mechanism involved in the last step in the process, namely $\mathrm{TH}$ secretion, remains unknown.

The close correlation between the free $\mathrm{TH}$ concentration in serum and the level of its intracellular action has perpetuated the notion of passive hormone diffusion through the lipid bilayer (7). Over the years, potential membrane transporters have been identified $(8,9)$, among which is monocarboxylate transporter 8 (MCT8). Rat Mct8 was shown to function as a specific TH transmembrane transporter (10). Uptake of labeled $\mathrm{T}_{4}$ and $\mathrm{T}_{3}$ by Mct 8 was potently inhibited by unlabeled $T_{4}$ and $T_{3}$, by the $T_{3}$ analogs $3,3^{\prime}, 5$-triiodo-

Conflict of interest: The authors have declared that no conflict of interest exists. Citation for this article: J Clin Invest. 2010;120(9):3377-3388. doi:10.1172/JCI42113. thyroacetic acid and $N$-bromoacetyl-3, $3^{\prime}, 5-\mathrm{T}_{3}$, and by the organic anion bromosulfophthalein, but not by aromatic amino acids. The mechanisms by which rat and human MCT8 facilitate TH uptake are still unknown. It has been demonstrated that this transport is $\mathrm{Na}$ independent (10), while its dependence on $\mathrm{pH}$ needs to be investigated (11). The dogma of passive TH entry into cells was only recently abandoned with the demonstration that humans harboring MCT8 gene mutations presented with debilitating psychomotor abnormality suggestive of TH deficiency in brain (12, 13). In addition, they manifested a characteristic though unusual combination of $\mathrm{TH}$ abnormalities consisting of high $\mathrm{T}_{3}$ and low $T_{4}$ and reverse $T_{3}\left(r T_{3}\right)$, associated with normal or slightly elevated serum thyrotropin (TSH) levels $(12,13)$. The TH abnormalities have been faithfully reproduced in Mct8-KO mice $(14,15)$, which have provided much-needed insight into the mechanism responsible for the thyroid phenotype. They continue to be a useful tool in understanding the pathophysiology of Mct8 defects and in testing $\mathrm{TH}$ analogs as putative treatment agents (16-18). Initial studies on these mice demonstrated overall increased $5^{\prime}$ deiodination (14, 15); however, the postulated consumptive effect on $T_{4}$ through increased 5 ' deiodination cannot fully explain the low serum $\mathrm{T}_{4}$ levels observed in MCT8 deficiency.

Our preliminary finding that in Mct8-KO mice, serum TH concentrations are reduced early following the release of endogenous hormone suppression with methimazole and perchlorate, raised the question of a possible defect in thyroidal TH secretion in Mct8 deficiency. Moreover, the fact that Mct8 is localized at the basolateral membrane of thyrocytes suggests that Mct8 might play a role in TH secretion. The possible role of MCT8 in TH export was previously shown by in vitro transfection studies of human MCT8 in mammalian cell lines (19).

To further investigate the kinetics of $\mathrm{TH}$ secretion, we measured, in Mct8-KO and WT mice, the release of labeled iodothyronines from the thyroid gland following the administration of radioio- 


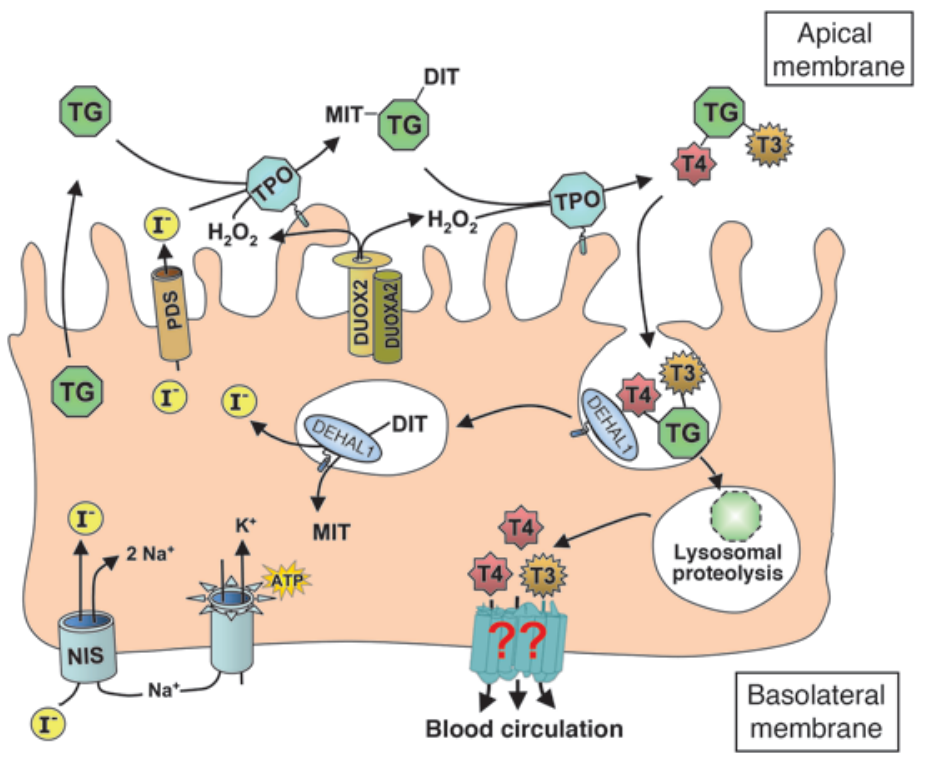

Figure 1

Diagrammatic representation of the steps involved in TH synthesis. All have been characterized at the molecular level, except for that involved in TH secretion. The latter, mediated through putative transporters, is indicated by question marks.

$\mathrm{T}_{4}$ and $\mathrm{T}_{3}$ levels started to rise in the serum of all mice. However, the increase in the Mct8-KO mice compared with that in the WT mice was significantly lower. In fact, serum $\mathrm{T}_{4}$ levels were in $M c t 8-\mathrm{KO}$ and WT mice $1.03 \pm 0.11$ and $1.95 \pm 0.21$ $\mu \mathrm{g} / \mathrm{dl}(P<0.001)$, respectively; $\mathrm{T}_{3}$ levels were paradoxically lower in $M c t 8-\mathrm{KO}$ mice $(179.0 \pm 8.7 \mathrm{ng} / \mathrm{dl})$ compared with WT mice $(235.2 \pm 12.5 \mathrm{ng} / \mathrm{dl} ; P<0.0001)$ (Figure 2 , A and B), and they were associated with higher TSH (7,173 \pm 594 vs. $4,937 \pm 323 \mathrm{mU} / 1, P=0.04)$. In contrast, the thyroid gland content of non-Tg- $\mathrm{T}_{4}$ and non-Tg- $\mathrm{T}_{3}\left(\mathrm{~T}_{4}\right.$ and $\mathrm{T}_{3}$ in thyroid gland not within the Tg molecule) in the Mct8-KO mice was 2.1-fold $(P=0.0002)$ and 3.4-fold $(P<0.0001)$ higher, respectively, than that in WT littermates (Figure 2, C and D). The content of $\mathrm{Tg}-\mathrm{T}_{4}$ and $\mathrm{Tg}-\mathrm{T}_{3}\left(\mathrm{~T}_{4}\right.$ and $\mathrm{T}_{3}$ contained within the $\mathrm{Tg}$ molecule) for the 2 genotypes was not statistically dif-

dide and the secretion of stable $\mathrm{T}_{4}$ following $\mathrm{TSH}$ stimulation. We found a significant reduction in the release of labeled iodothyronines as well as that of stable $\mathrm{T}_{4}$ in the $M c t 8-\mathrm{KO}$ compared with the WT mice. These data, in addition to the higher TH content in the thyroid glands of Mct8-KO mice and a slower reduction in their thyroidal TH content during iodine deficiency, provide evidence of a novel role of MCT8, namely, control of TH secretion. This reduction in $\mathrm{TH}$ secretion caused by MCT8 deficiency contributes in part to the low serum $\mathrm{T}_{4}$ levels observed in mice and humans. ferent (Table 1). Three days after withdrawal of LoI/MMI/ClO the serum $\mathrm{T}_{4}$ levels were still lower in the Mct8-KO mice, but their serum $\mathrm{T}_{3}$ levels increased above those of WT mice. The characteristic thyroid function tests abnormalities present in the Mct8-KO mice, low-serum $\mathrm{T}_{4}$ and high $\mathrm{T}_{3}$ levels, appeared on the third day after resumption of the TH synthesis. The thyroid gland of Mct8$\mathrm{KO}$ mice continued to contain significantly more non-Tg- $\mathrm{T}_{4}$ and non-Tg-T $3(P<0.0001)$ than the glands of WT mice.

In order to determine whether intrathyroidal deiodination played a role in the relatively greater difference of the non- $\mathrm{Tg}-\mathrm{T}_{3}$ to non- $\mathrm{Tg}-\mathrm{T}_{4}$

\section{Results}

Recovery of TH synthesis and secretion after chemical suppression. After 2 weeks of treatment with low-iodine diet, methimazole, and perchlorate (LoI/MMI/ClO 4 ), sufficient to almost completely deplete the thyroid gland of $\mathrm{TH}$, serum $\mathrm{T}_{4}$ was suppressed to less than $0.2 \mu \mathrm{g} / \mathrm{dl}$ and $\mathrm{T}_{3}$ to concentrations from 64 to $68 \mathrm{ng} / \mathrm{dl}$, while TSH increased to levels ranging from 7,204 to 7,408 $\mathrm{mU} / 1$ (normal range, $10-60 \mathrm{mU} / \mathrm{l})$, irrespective of the mouse genotype. One day after withdrawal of LoI/MMI/ $\mathrm{ClO}_{4}$, resulting in the resumption of TH synthesis,

\section{Figure 2}

The dynamics of rebound of TH synthesis and secretion after chemical suppression was stopped. Shown are serum total $\mathrm{T}_{4}(\mathrm{~A})$ and total $\mathrm{T}_{3}(\mathrm{~B})$ concentrations and thyroidal non- $\mathrm{Tg}-\mathrm{T}_{4}(\mathrm{C})$ and non- $\mathrm{Tg}-\mathrm{T}_{3}$ (D) content $\left(T_{4}\right.$ and $T_{3}$ in the thyroid gland not within the $T g$ molecule) at baseline and at 0,1 , and 3 days after withdrawal of $\mathrm{Lol} / \mathrm{MMI} / \mathrm{ClO}_{4}$. Data are expressed as mean \pm SEM. At 1 day, serum $\mathrm{T}_{4}$ and $\mathrm{T}_{3}$ levels in Mct8-KO mice were significantly lower as compared with those in WT mice ( $\mathbf{A}$ and $\mathbf{B}$ ); in contrast, their thyroid gland content of non- $\mathrm{Tg}-\mathrm{T}_{4}$ and $\mathrm{Tg}-\mathrm{T}_{3}$ was significantly higher ( $\mathbf{C}$ and $\mathbf{D})$. The characteristic thyroid function test abnormalities of Mct8-KO mice manifested only on the third day after resumption of the TH synthesis. ${ }^{\star \star} P<0.01,{ }^{\star \star \star} P<0.001,{ }^{\dagger} P<0.0001$.
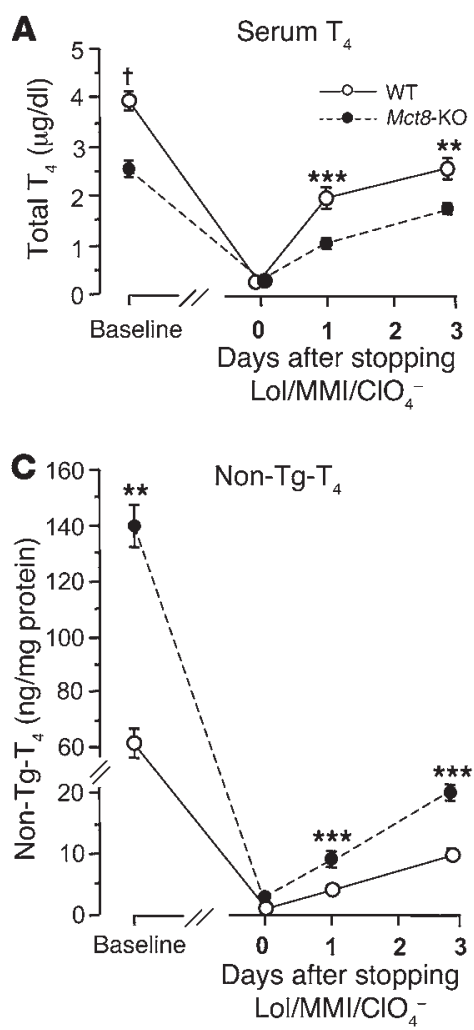

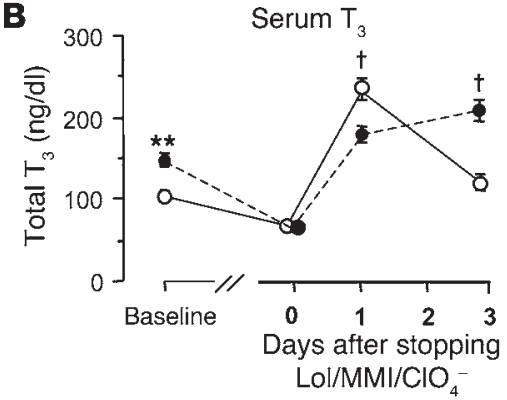

D

Non-Tg-T

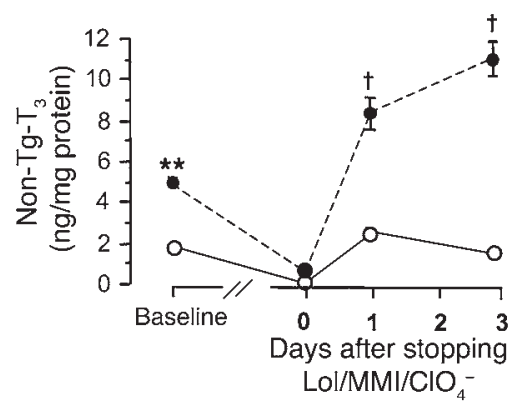




\section{Table 1}

Intrathyroidal $\mathrm{Tg}-\mathrm{T}_{4}$ and $\mathrm{Tg}-\mathrm{T}_{3}$ of WT and Mct8-KO mice at 0 and 1 day after withdrawal of $\mathrm{Lol} / \mathrm{MMI} / \mathrm{ClO}_{4}$

\begin{tabular}{lcccc} 
& \multicolumn{2}{c}{$\mathrm{Tg}-\mathrm{T}_{\mathbf{4}}$ (ng/mg protein) } & \multicolumn{2}{c}{$\mathrm{Tg}-\mathrm{T}_{3}$ (ng/mg protein) } \\
& WT & Mct8-KO & WT & Mct8-KO \\
0 days & $7.54 \pm 1.78$ & $6.70 \pm 2.75^{\mathrm{A}}$ & $7.72 \pm 3.01$ & $5.00 \pm 0.34^{\mathrm{A}}$ \\
1 day & $46.64 \pm 9.58$ & $53.56 \pm 8.46^{\mathrm{A}}$ & $11.93 \pm 1.29$ & $14.89 \pm 2.52^{\mathrm{A}}$ \\
\hline
\end{tabular}

Values are expressed as mean \pm SEM. ${ }^{A} P>0.05$ versus $W T$.

ratio in $M c t 8-\mathrm{KO}$ compared with WT mice (at day $1: 1.03 \pm 0.18$ vs. $0.61 \pm 0.07$; at day $3: 0.55 \pm 0.02$ vs. $0.16 \pm 0.02$ ), we measured the D1 enzymatic activity in their thyroid glands at 1 and 3 days after stopping LoI $/ \mathrm{MMI} / \mathrm{ClO}_{4}$. No significant differences were found at either time (at day 1: $531.5 \pm 52.1$ vs. $535.7 \pm 32.3 \mathrm{pmol} / \mathrm{h} / \mathrm{mg}$ protein; at day $3: 482.0 \pm 33.9$ vs. $501.8 \pm 14.3 \mathrm{pmol} / \mathrm{h} / \mathrm{mg}$ protein). These data show that the lower serum $\mathrm{T}_{4}$ and $\mathrm{T}_{3}$ levels of $M c t 8$-KO mice early after stopping suppression of TH synthesis cannot be explained by changes in deiodination. More importantly, the higher intrathyroidal content of non- $\mathrm{Tg}-\mathrm{T}_{4}$ and non- $\mathrm{Tg}-\mathrm{T}_{3}$ in $\mathrm{Mct}$ - $\mathrm{KO}$ mice, associated with the lower TH levels in the serum, indicate that Mct8-KO mice might have a defect in TH secretion.

Localization of Mct8 in the thyroid gland. To examine whether Mct8 was expressed in the thyroid gland and determine its subcellular distribution, we prepared frozen sections from thyroid glands of WT and Mct8-KO mice. The sections were stained with an antibody against the carboxyl terminus of the mouse Mct8 molecule and imaged on a confocal microscope. Mct8 was localized at the basolateral membrane of thyroid follicular cells, compatible with a putative export function (Figure 3A). No Mct8 labeling was detected in thyroid sections from the $M c t 8$-KO mice. Immunoblot analysis con- firmed that Mct8 was expressed in the thyroid glands of WT animals but not in those of Mct8-KO mice (Figure 3B).

Thyroid gland weight, histology, and TH content. Thyroid glands were significantly bigger in the Mct8-KO mice. At 14 weeks of age, mean thyroid gland weights of WT and Mct8-KO mice were $2.6 \pm 0.3$ and $4.1 \pm 0.2 \mathrm{mg}$, respectively $(P<0.001)$, with thyroid weight to body weight (BW) ratios of $0.093 \pm 0.01$ and $0.16 \pm 0.01 \mathrm{mg} / \mathrm{g}$, respectively $(P<0.001)$. On initial microscopic examination, the sections stained with $\mathrm{H} \& \mathrm{E}$ showed no gross histological differences between the two genotypes (Figure 4A). However, quantitative examination of 200 thyroid follicles/ genotype with ImageJ software showed that Mct8-KO mice had an increase in the whole follicle area as compared with the WT mice, due to an increase of both thyrocyte and colloid areas, while the mean number of thyrocytes per follicle was similar in the two genotypes (Figure 4B).

At 14 weeks, thyroid glands of $M c t 8-K O$ mice contained 2.3-fold $(P<0.001)$ and 1.5 -fold $(P<0.01)$ more non-Tg- $\mathrm{T}_{4}$ and non-Tg- $\mathrm{T}_{3}$, respectively, than WT mice. Figure 5, A and B, shows data obtained in 14 mice per genotype. The difference was significant whether expressed as nanograms of the hormone per thyroid weight or per amount of protein (the latter is shown in Figure 5). The non-Tg- $\mathrm{T}_{3}$ to non- $\mathrm{Tg}-\mathrm{T}_{4}$ ratio was not significantly different.

Similarly, the levels of $\mathrm{Tg}-\mathrm{T}_{4}$ and $\mathrm{Tg}-\mathrm{T}_{3}$ were significantly increased in the thyroid glands of Mct8-KO mice (Figure 5, C and D). At 14 weeks, the thyroidal content of $\mathrm{Tg}_{-}-\mathrm{T}_{4}$ in $\mathrm{WT}$ mice was $1,381 \pm 77$ and in $M c t 8$-KO mice, $2,579 \pm 173 \mathrm{ng} / \mathrm{mg}$ protein $(P<0.001)$; the $\mathrm{Tg}-\mathrm{T}_{3}$ in WT mice was $88.2 \pm 6.4 \mathrm{ng} / \mathrm{mg}$ protein and in $\mathrm{Mct} 8 \mathrm{-KO}$ mice, $188.3 \pm 13.3 \mathrm{ng} / \mathrm{mg}$ protein $(P<0.001)$. The $\mathrm{Tg}-\mathrm{T}_{3}$ to $\mathrm{Tg}-\mathrm{T}_{4}$ ratio was again not significantly different between the two genotypes.

In order to determine whether these abnormalities in thyroidal $\mathrm{TH}$ content were already present at younger age, we examined the
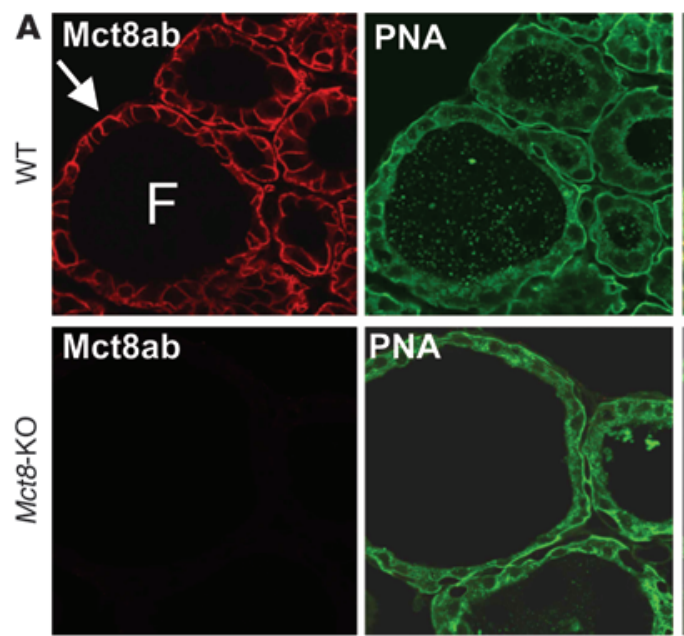
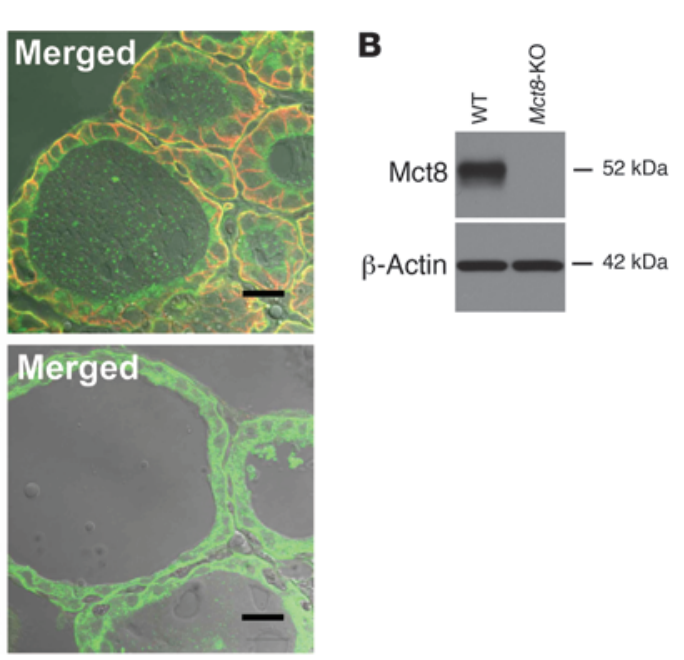

\section{Figure 3}

Intrathyroidal expression and localization of the Mct8 protein. (A) Immunoconfocal images from cryosections of thyroid glands prepared from WT and Mct8-KO mice colabeled with anti-Mct8 antibody (red) and PNA lectin (green). Merged images are shown overlaid on the differential interference contrast image. Mct8 immunolabeling was detected at the basolateral membrane of thyrocytes (arrow) of WT mice, while no labeling was detected in thyroid sections from Mct8-KO mice. PNA lectin labeled the thyrocyte plasma membranes in sections from both WT and Mct8KO mice. F, follicle. Scale bars: $20 \mu \mathrm{m}$. (B) Immunoblot analysis of detergent-soluble protein lysates prepared from thyroid glands of WT and Mct8-KO mice probed with antibodies to Mct8 and to $\beta$-actin as a loading control. Samples from WT mice show a band of $52 \mathrm{kDa}$, corresponding to Mct8. This band was absent in samples from Mct8-KO mice. 
A

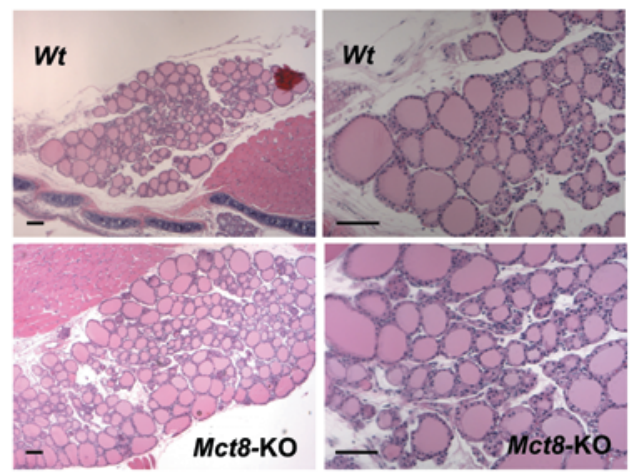

B
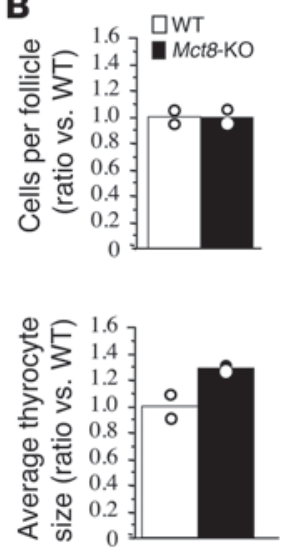
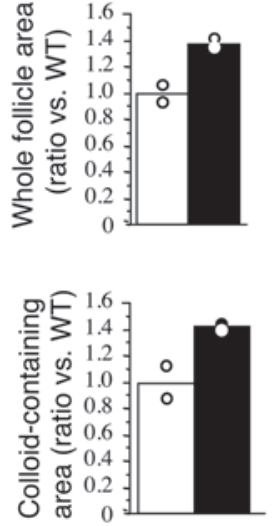

thyroid glands of $6 \mathrm{Mct}$-KO mice and 6 WT littermates 18 days after birth (2.6 weeks). At this age, the Mct8-KO mice already had the characteristic thyroid function test abnormalities, a lower serum $\mathrm{T}_{4}$ level than WT mice $(1.3 \pm 0.1 \mathrm{vs} .5 .1 \pm 0.3 \mu \mathrm{g} / \mathrm{dl}, P<0.001)$ and higher $\mathrm{T}_{3}(127 \pm 3$ vs. $99 \pm 5 \mathrm{ng} / \mathrm{dl}, P=0.001)$ and TSH levels ( $45 \pm 11$ vs. $15 \pm 3 \mathrm{mU} / 1, P=0.03$ ). As in older mice, the thyroidal content of non- $\mathrm{Tg}-\mathrm{T}_{4}$ and non-Tg- $\mathrm{T}_{3}$ in $\mathrm{Mct}$ - $\mathrm{KO}$ mice was higher than in the WT mice (Figure 5, A and B). However, unlike in the 14-week-old mice, the content of Tg-TH was not different between the two genotypes (Figure 5, C and D). The observation that the difference in non- $\mathrm{Tg}-\mathrm{T}_{4}$ and non- $\mathrm{Tg}-\mathrm{T}_{3}$ was present at a younger age but that of $\mathrm{Tg}-\mathrm{T}_{4}$ and $\mathrm{Tg}-\mathrm{T}_{3}$ became significant only at a later age suggests that the reduction in the secretion of iodothyronines might be responsible for the intrathyroidal accumulation of stored iodothyronines.

Kinetics of TH secretion. The data presented above, indirectly suggesting a putative role of Mct8 on TH secretion, prompted us to carry out further experiments. Eight Mct8-KO mice and 8 WT littermates were fed low-iodine diet for 2 weeks. After the i.p. administration of $5 \mu \mathrm{Ci}{ }^{125} \mathrm{I}$, the amount of radioactivity in thyroid glands and that in serum were deter-

\section{Figure 5}

Thyroidal TH content. Non- $\mathrm{Tg}-\mathrm{T}_{4}(\mathbf{A})$ and non- $\mathrm{Tg}-\mathrm{T}_{3}(\mathrm{~B})$ $\left(T_{4}\right.$ and $T_{3}$ in the thyroid gland not within the $\mathrm{Tg} \mathrm{mol}-$ ecule), and $\mathrm{Tg}-\mathrm{T}_{4}(\mathrm{C})$ and $\mathrm{Tg}-\mathrm{T}_{3}(\mathrm{D})\left(\mathrm{T}_{4}\right.$ and $\mathrm{T}_{3}$ contained within the Tg molecule) of WT and Mct8-KO mice 2.6 and 14 weeks old. Bars represent the mean \pm SEM. ${ }^{\star} P<0.05,{ }^{* *} P<0.01,{ }^{* *} P<0.001$.

\section{Figure 4}

Histology of WT and Mct8-KO mouse thyroid glands. (A) Low- (left) and higher-power (right) views of H\&E-stained sections from thyroid glands of 14-week-old WT and Mct8-KO mice. Scale bars: $100 \mu \mathrm{m}$. (B) Morphometric analysis of thyroid gland sections showing the number of cells per follicle, whole follicle area, average thyrocyte size, and colloid-containing area (for details, see Methods). The data are expressed relative to WT and presented as mean and variance.

mined at different time intervals over the period of 72 hours. The peak thyroid ${ }^{125}$ I uptake occurred at 8 hours after the administration of the radioiodide in both genotypes and was of similar levels $(62.3 \% \pm 3.3 \%$ vs. $65.0 \% \pm 2.6 \%$ of injected dose in WT vs. Mct8$\mathrm{KO}$, respectively; NS), reflecting the similar levels of serum TSH in Mct8-KO and WT mice after 2 weeks of low-iodine diet (110 \pm 19 and $82 \pm 13 \mathrm{mU} / 1$, respectively; NS). Thereafter, thyroidal radioactivity decreased progressively (Figure 6A) while appearing in serum as trichloroacetic acid-precipitable (TCA-precipitable) radioactivity (Figure 6B). In the Mct8-KO mice, both the rate of radioiodine disappearance from the thyroid gland and the appearance of labeled iodothyronines in serum were significantly reduced (Figure 6, A and B). At 72 hours, the thyroid glands of Mct8-KO mice still contained $71 \%$ of the maximal ${ }^{125}$ I uptake, while the WT glands contained only $30 \%$ (Figure 6A). In agreement with the reduced secretion, at this time point the thyroidal content in radioactivity, measured as TCA-precipitable radioactivity after hydrolysis ( $\mathrm{Tg}$ iodothyronines) and without hydrolysis (non-Tg-iodothyronines), was 5.3-fold $(P<0.001)$ and 2.4-fold $(P=0.06)$, respectively, higher in Mct8-KO than WT mice. These findings indicate an accumulation of newly synthesized iodothyronines as a result of decreased secretion from the thyroid glands of Mct8-KO mice.

Secretion of stable $T_{4}$ from the thyroid gland. To confirm the data generated by the kinetic analysis of newly synthesized TH after depletion of the iodine stores, we measured the acute release of stable $\mathrm{T}_{4}$ in serum of animals with a normal iodine content after a single injection of $2 \mathrm{mU}$ of bovine TSH. Mct8-KO and WT mice were pretreated with supraphysiological doses of $\mathrm{L}^{-} \mathrm{T}_{3}(10 \mu \mathrm{g} / 100 \mathrm{~g}$ $\mathrm{BW} / \mathrm{d}$ for 4 days) to eliminate the effect of endogenous TSH and to reduce the basal concentration of $\mathrm{T}_{4}$ (see legend to Figure 7). As shown in Figure 7, the secretion of $\mathrm{T}_{4}$ was significantly reduced in the Mct8-KO as compared with the WT animals at
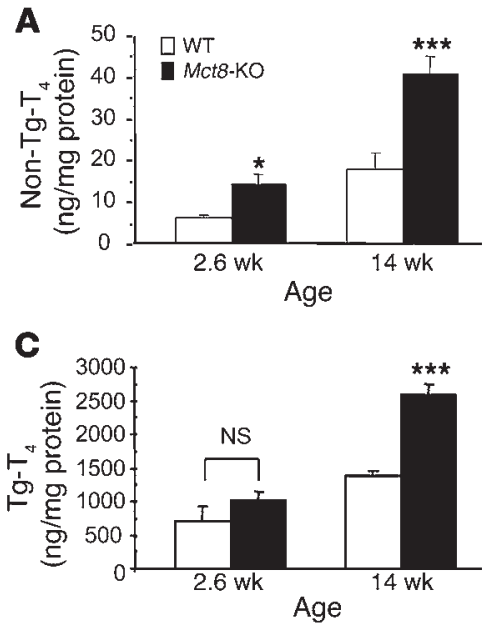
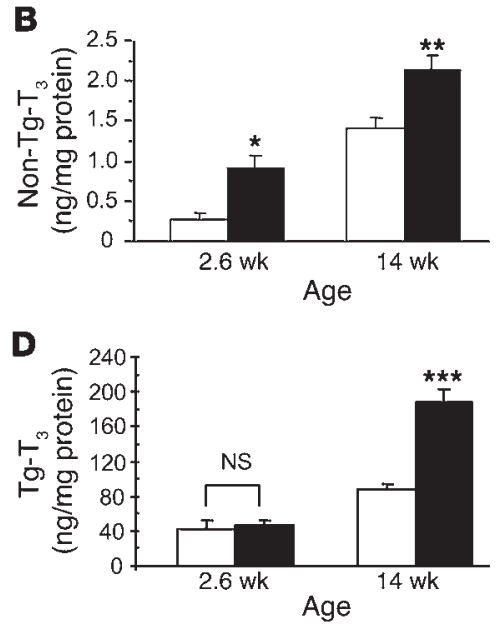

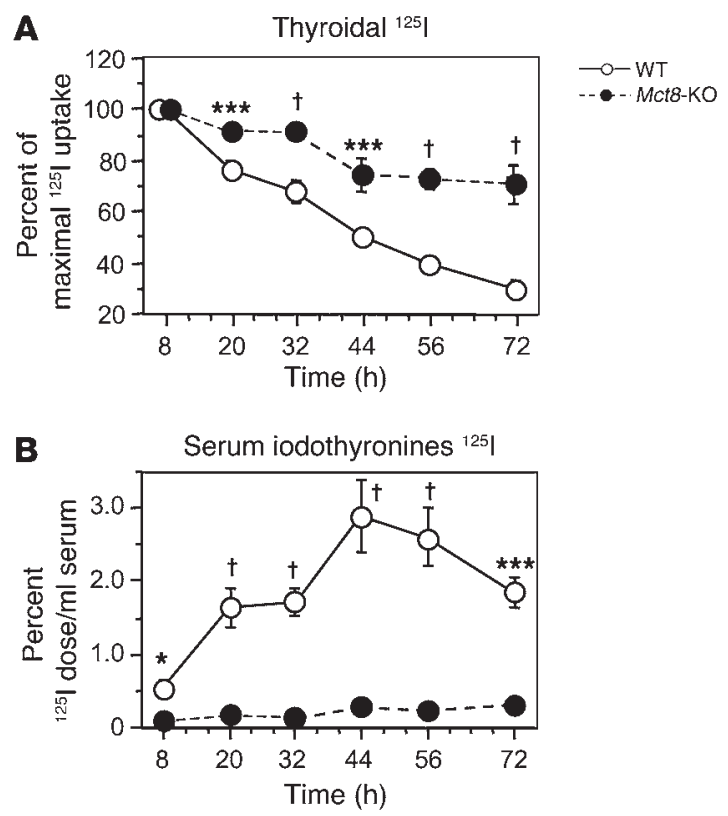

all time points after the administration of TSH. At 3 hours, corresponding to the peak serum $\mathrm{T}_{4}$ concentration, the mean $\mathrm{T}_{4}$ increment was $1.6 \pm 0.1$ vs. $1.2 \pm 0.1 \mu \mathrm{g} / \mathrm{dl}(P=0.004)$ in the WT and $\mathrm{Mct} 8 \mathrm{-KO}$ mice, respectively.

We next checked whether the decreased TH secretion in knockout mice was due to constitutive differences in the expression of the TSH receptor or in the expression of the genes that are regulated by TSH. No differences were found in these, measured at baseline, or in D1 enzymatic activity (Figure 8, A and B). These results provide further evidence that in the $\mathrm{Mct}$ - $\mathrm{KO}$ mice, there is an impairment in the efflux of $\mathrm{T}_{4}$ from the thyroid gland.

Thyroid function and thyroidal TH content in WT and Mct8-KO mice during the course of iodine depletion. The previous observation that the serum TSH levels did not increase after 2 weeks of treatment with low-iodine diet in the Mct8-KO mice remained unexplained. To understand whether this could be related to a defect in TH secretion of the Mct8-KO mice, we fed 4 different groups of 5-6 mice per genotype a low-iodine diet for 1, 2, 4, and 6 weeks, respectively. TSH, $\mathrm{T}_{4}$, and $\mathrm{T}_{3}$ concentrations in serum as well as the content of the two iodothyronines in the thyroid glands, both non-Tg-TH and Tg-TH, were measured in all the groups and compared with those in the untreated baseline group. Measurement in serum showed that the mean circulating TSH levels, lower at baseline in the WT mice, increased to reach the same values as in Mct8-KO mice after 1 week of low-iodine diet, then became significantly higher in the WT mice at 2 and 4 weeks and eventually reached the same levels in both genotypes at 6 weeks (Figure 9A). This trend reflected the progressive and greater increase in TSH levels in the WT mice during the initial 2 weeks of iodine deficiency. Compared with that in the WT mice, the serum TSH in the Mct8-KO mice increased significantly relative to baseline values only after 4 and 6 weeks of low-iodine diet. As a consequence of the serum TSH rise in both genotypes, the thyroid gland weights increased, producing at 4 weeks histological features typical of hyperplastic goiter (Figure 9, D and E). The difference in magnitude of the TSH increase between WT and Mct8-KO mice could be explained by the greater decrease in serum $\mathrm{T}_{4}$ values in the WT

\section{Figure 6}

Kinetic TH secretion from the thyroid gland of WT and Mct8-KO mice. Adult animals were given ${ }^{125}$, and, at indicated time intervals, the radioactivity was determined in their thyroid glands by counting in vivo and in serum samples (see Methods). Results of thyroidal radioactivity are expressed as percent of the maximal ${ }^{125}$ uptake, being $100 \%$ at 8 hours $(\mathbf{A})$. The results of serum TCA-precipitable radioactivity (iodothyronines ${ }^{125}$ ) are expressed as percentage of the injected ${ }^{125}$ dose per milliliter of serum (B). ${ }^{*} P<0.05,{ }^{* * *} P<0.001,{ }^{\dagger} P<0.0001$.

than in the Mct8-KO mice (Figure 9B). In fact, at 2 weeks, whereas in the WT the serum $\mathrm{T}_{4}$ levels were only $17.8 \%$ of their baseline values, in the Mct8-KO they were still 45\% (Figure 9B). We could not correlate exactly TSH and $\mathrm{T}_{4}$ values at 4 and 6 weeks, because the latter were in both genotypes below the limit of detection for our assay. The pattern of changes in circulating $T_{3}$ was different from that described for $T_{4}$. In the WT mice, serum $T_{3}$ increased after 1 week, then decreased again to baseline values and remained stable in all the following weeks of treatment (Figure 9C). This is compatible with preferential production of $\mathrm{T}_{3}$ present in conditions of iodine deficiency $(20,21)$. Similarly, in the Mct8-KO mice, serum $\mathrm{T}_{3}$ remained stable and equal to the baseline values until 2 weeks but decreased significantly at 4 and 6 weeks, reaching at 6 weeks the same absolute levels as in WT mice (Figure 9C).

Measurement of the thyroid gland content of iodothyronines showed that in Mct8-KO mice the rate of decrease in $\mathrm{Tg}-\mathrm{T}_{4}$ and $\mathrm{Tg}-\mathrm{T}_{3}$ content was lesser than in WT mice at 1 and 2 weeks (Figure 10, A and B). By the 4th and 6th weeks, WT and Mct8-KO mice showed the same values, which were at the limit of the assay detection. In contrast, the content of non- $\mathrm{Tg}-\mathrm{T}_{4}$ and non- $\mathrm{Tg}-\mathrm{T}_{3}$ decreased less in Mct8-KO than WT mice until 4 weeks, when their levels in the thyroid were still higher than in WT mice (Figure 10, C and D).

These data show that in a condition in which the TH synthesis is reduced or inhibited, as in iodine deficiency, because of a defect in $\mathrm{TH}$ hormone secretion in Mct8-KO mice, the depletion in the thyroidal hormone content is slower, especially in non-Tg-hormone content. As a consequence, compared with WT mice, Mct8-KO mice can maintain relatively higher serum $\mathrm{TH}$ levels for a longer time.

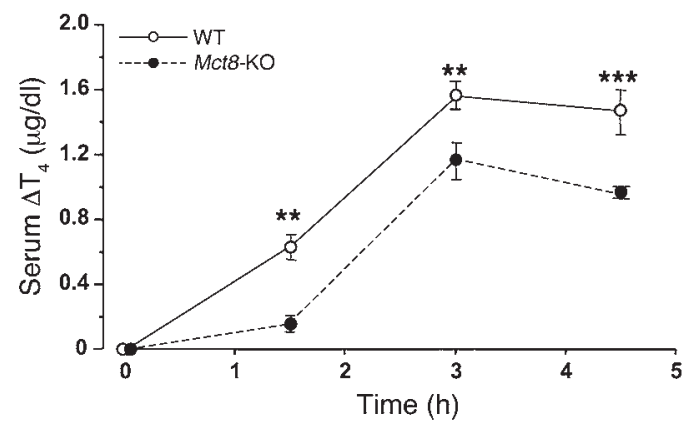

\section{Figure 7}

$\mathrm{T}_{4}$ secretion following the administration of TSH. Mice were pretreated with $\mathrm{L}-\mathrm{T}_{3}$ in order to suppress endogenous $\mathrm{TSH}$ and $\mathrm{T}_{4}$ prior to the administration of bovine TSH. Serum $\mathrm{T}_{4}$ concentration was measured before and 1.5, 3, and 4.5 hours after injection. The response of $\mathrm{T}_{4}$ was significantly reduced in the Mct8-KO as compared with WT mice at all time points. At time 0 (after $\mathrm{L}^{-\mathrm{T}_{3}}$ treatment), serum $\mathrm{T}_{4}$ was $0.36 \pm 0.02$ and $0.44 \pm 0.10 \mu \mathrm{g} / \mathrm{dl}$ in the WT and Mct8-KO mice, respectively (NS). Values are expressed as mean \pm SEM of serum $\mathrm{T}_{4}$ increment. ${ }^{* *} P<0.01,{ }^{* *} P<0.001$. 
A

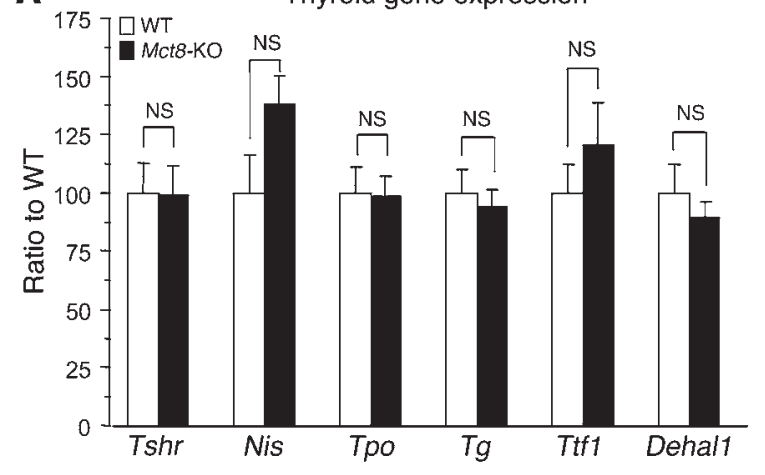

B D1 enzymatic activity

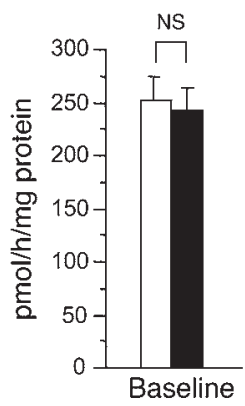

\section{Figure 8}

Effect of Mct8 deficiency on the expression of genes that regulate thyroid gland activity, hormone synthesis, and metabolism. (A) The transcript levels of the TSH receptor and genes regulated by $\mathrm{TSH}$ and $(\mathrm{B})$ the enzymatic activity of D1 in the thyroid glands of Mct8-KO and WT mice. Values in $\mathbf{A}$ are relative to WT. Data are expressed as mean \pm SEM.
Expression of TH transporters in thyroid glands. To determine whether there is redundancy in the expression of TH transporters in the thyroid gland, we measured by quantitative PCR (qPCR) the mRNA levels of $M c t 8$ and the other putative TH transporters in the WT mouse. As shown in Figure 11A, Mct 8 was most abundantly expressed. Compared with Mct8, Mct10 was expressed at $14 \%$, Lat1 at $0.9 \%$, and Lat 2 at $0.5 \%$. Other TH transporters were undetectable (Table 2). In search for compensatory mechanisms, we also looked for differences in the mRNA levels of Mct10, Lat1, and Lat2 in Mct8$\mathrm{KO}$ as compared with WT mice and found none (Figure 11B).

\section{Discussion}

The mechanism involved in the secretion of TH from the thyroid gland into the blood circulation has remained up to now an enigma. For many years, this process has been commonly attributed to passive diffusion of the small lipophilic hormone molecules through the plasma membrane of thyrocytes (22). This statement, however, ignores the fact that secretion of $\mathrm{TH}$ is a polarized process; the hormone is released across the basolateral membrane of thyroid follicular cells, adjacent to the capillary bed. In addition, studies from different laboratories over the past few decades have shown that influx and efflux of both $\mathrm{T}_{3}$ and $\mathrm{T}_{4}$ across plasma membrane requires facilitated and/or active transport systems $(8,9,23)$. From these data, it seems reasonable to postulate the existence of a putative transport system localized at the basolateral membrane of thyrocytes.

In the present work, we have addressed the role of Mct8 in $\mathrm{TH}$ secretion. To accomplish this goal, we used Mct8-KO mice, which we generated by homologous recombination (14). Characterizing the phenotype of these mice revealed that Mct8 mediates, at least in part, the transport of TH from the thyrocytes into the bloodstream.

As shown by us and another group $(14,15), M c t 8$-KO mice fully replicate the endocrine aberrances observed in humans, including a low concentration of the precursor $\mathrm{T}_{4}$. This latter finding cannot be fully accounted for by the tissue-specific increase in D1 and D2 and decrease in D3 activities or by the defective TH cell entry, found in Mct8-KO mice and considered so far as the mechanisms responsible for the thyroid phenotype in humans and mice $(14,15)$.

We studied the sequence in which thyroid function test abnormalities develop in Mct8-KO mice from birth to adulthood (24) and found that low serum $T_{4}$ precedes the increase in serum $T_{3}$ levels, suggesting that another mechanism in addition to that of $\mathrm{T}_{4}$ consumption through excess deiodination is responsible for the low serum $\mathrm{T}_{4}$ level in $M c t 8$-KO mice. The idea that the low serum $\mathrm{T}_{4}$ concentration could result from a defect in its secretion from the thyroid gland and therefore the involvement of Mct8 in this process was suggested by the pattern of $\mathrm{T}_{4}$ and $\mathrm{T}_{3}$ release after stopping suppression of endogenous $\mathrm{TH}$ production. After 2 weeks of treatment with methimazole, perchlorate, and low-iodine diet, $\mathrm{T}_{4}$ and $\mathrm{T}_{3}$ levels were suppressed to the same level in both genotypes. The amount of $\mathrm{T}_{4}$ and $\mathrm{T}_{3}$ in serum measured early following release of chemical blockage was significantly lower in Mct8-KO compared with the WT mice. The characteristic high serum $\mathrm{T}_{3}$ of Mct8 deficiency manifested later. In contrast to serum, thyroid gland content of non- $\mathrm{Tg}-\mathrm{T}_{4}$ and non-Tg- $\mathrm{T}_{3}$ in Mct8-KO mice was significantly higher than that of WT littermates, indicating that the thyroid glands of Mct8-KO mice might have a defect in the release of hormone into the circulation. The finding that Mct8-KO mice accumulate larger amounts of non-Tg-TH in their thyroid glands was confirmed in other measurements performed in mouse thyroid glands in the basal condition. The thyroid glands of Mct8-KO mice contained at baseline 2.3- $(P<0.001)$ and 1.5 -fold $(P<0.01)$ more non- $\mathrm{Tg}-\mathrm{T}_{4}$ and non-Tg- $\mathrm{T}_{3}$, respectively, than WT mice. The measurement of $\mathrm{TH}$ content after hydrolysis of $\mathrm{Tg}$ showed that the same mice also accumulated in their thyroid glands Tg-bound hormones (almost double the amount of $\mathrm{Tg}-\mathrm{T}_{4}$ and $\mathrm{Tg}-\mathrm{T}_{3}$ than in WT mice). This latter phenomenon seems to be a consequence of the progressive accumulation of the non- $\mathrm{Tg}$ hormonal fractions. In fact, while we found an increased content of non-Tg-TH already in 2.6-week-old mice, the increase of Tg-TH manifested only in the adult mice (14 weeks old). It is possible that the progressive accumulation of non-Tg-hormones in the thyrocytes inhibits the endocytosis and/or degradation of $\mathrm{Tg}$. However, the mechanism involved requires further investigation. The increased colloid areas in the thyroid glands of Mct8-KO mice, observed on morphological examination, reflects this increase in the TH content. Of note is that the $T_{3}$ to $T_{4}$ ratio either as non- $T g$ - or as $T g$-hormones was conserved in the thyroids of $\mathrm{Mct} 8-\mathrm{KO}$ mice, indicating that there is no preferential synthesis of $\mathrm{T}_{4}$ and/or generation of $\mathrm{T}_{3}$. The enzymatic activity of iodothyronine deiodinase 1 in the thyroid gland was not increased in Mct8-KO mice. Furthermore, mice deficient in both Mct8 and the two deiodinases, 1 and 2, had higher intrathyroidal non- $\mathrm{Tg}-\mathrm{T}_{3}$ and non- $\mathrm{Tg}-\mathrm{T}_{4}$ content than mice deficient in the deiodinases only (our unpublished observations). Thus, intrathyroidal deiodinases have no role in the observed accumulation of non-Tg-TH in Mct8-KO mice.

The immunohistochemical localization of the Mct8 protein at the basolateral membrane of thyrocytes (secretory surface) lent further credence to the hypothesis that this transporter is involved in hormone secretion. However, only the results of the 

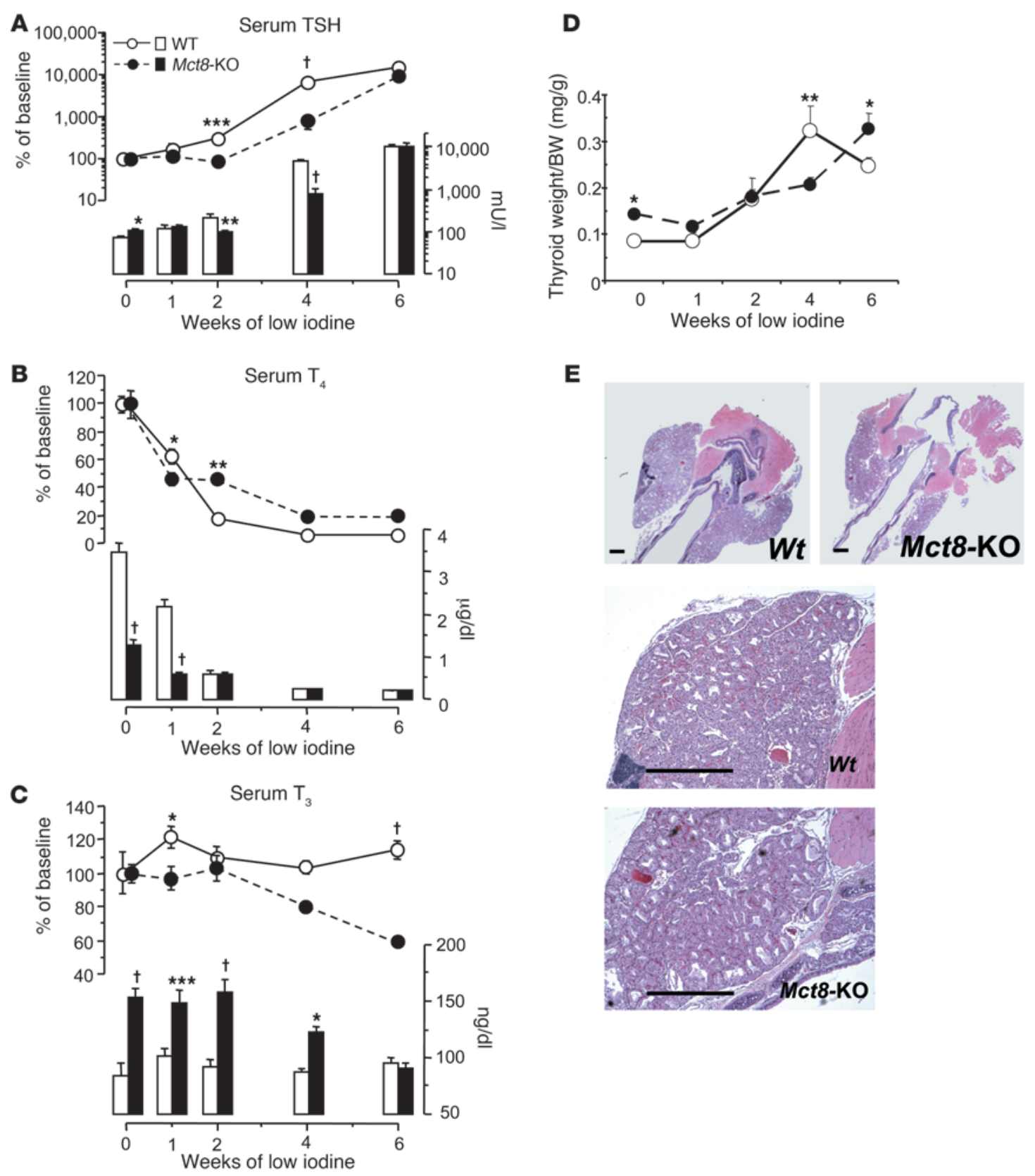

Figure 9

Effect of low-iodine diet on thyroid function of WT and Mct8-KO mice. Shown are serum TSH (A), $\mathrm{T}_{4}(\mathbf{B})$, and $\mathrm{T}_{3}(\mathbf{C})$ concentrations. Values are expressed in absolute amount (bars) and as percentage of the mean baseline value of the corresponding genotype (lines). (D) Effect of TSH increase produced by low-iodine diet on thyroid gland weight. Data are expressed as mean \pm SEM. (E) Low- (top panels) and higher-power (bottom panels) views of H\&E-stained sections from thyroids of WT and Mct8-KO mice after 4 weeks of low-iodine diet. The rise in serum TSH in both genotypes produced typical histological features of hyperplastic goiter (compare sections from untreated mice, Figure 4A). Note the larger glands of WT animals at 4 weeks. Scale bars: $500 \mu \mathrm{m} .{ }^{\star} P<0.05,{ }^{\star \star} P<0.01,{ }^{\star \star \star} P<0.001,{ }^{\dagger} P<0.0001$.

experiments assessing directly the secretion allowed us to demonstrate this new role of MCT8.

Administration of ${ }^{125} \mathrm{I}$ to $M c t 8-\mathrm{KO}$ and WT mice was used to determine the rate of iodothyronine secretion in vivo. The peak thyroidal uptake of ${ }^{125}$ I occurred at the same time and reached the same values in the Mct8-KO and WT mice, in agreement with their similar TSH levels after 2 weeks of low-iodine diet. However, in Mct8-KO mice, there was a marked reduction in the rate of thy- roidal release and appearance of the labeled hormones in serum. According to the "last-come-first-served" phenomenon $(25,26)$, the latter represent the newly synthesized iodothyronines. At 72 hours, the very low levels of labeled hormones in serum of Mct8$\mathrm{KO}$ mice were associated with a high degree of retention of the maximal ${ }^{125}$ I taken by the gland $(71 \%$ vs. the $30 \%$ present in the thyroid glands of WT mice). Consistent with a defective secretion, measurement of thyroidal content in radioactivity after TCA 


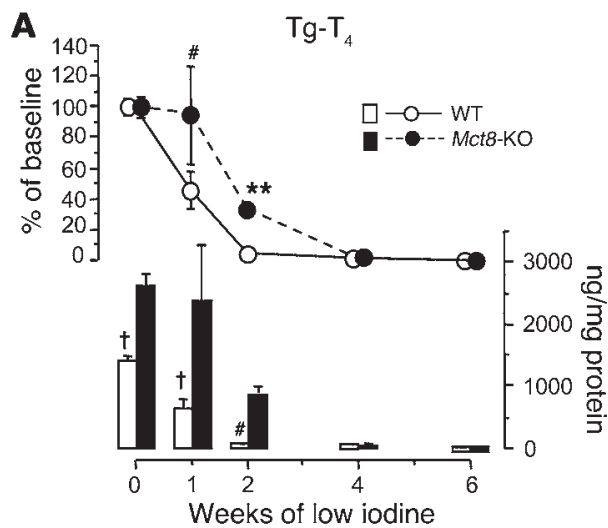

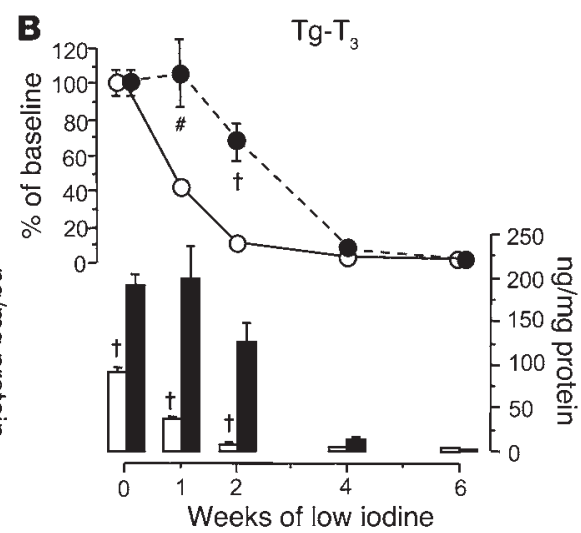

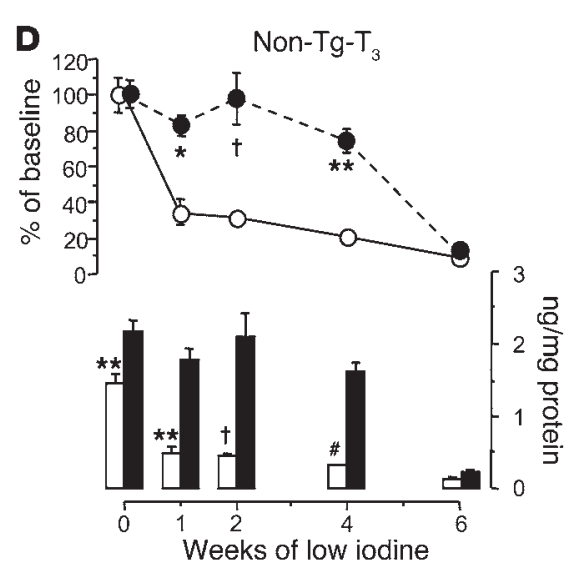

\section{Figure 10}

Effect of low-iodine diet on thyroidal TH content of WT and Mct8-KO mice. Content of $\mathrm{Tg}-\mathrm{T}_{4}(\mathbf{A})$ and $\mathrm{Tg}-\mathrm{T}_{3}(\mathrm{~B})\left(\mathrm{T}_{4}\right.$ and $\mathrm{T}_{3}$ contained within the $\mathrm{Tg}$ molecule) and non- $\mathrm{Tg}-\mathrm{T}_{4}$ (C) and non- $\mathrm{Tg}-\mathrm{T}_{3}$ (D) $\left(\mathrm{T}_{4}\right.$ and $\mathrm{T}_{3}$ in the thyroid gland not within the $\mathrm{Tg}$ molecule). Values are expressed in absolute amount (bars) and percentage of the mean baseline value of the corresponding genotype (lines). ${ }^{\star} P<0.05,{ }^{\star \star} P<0.01,{ }^{\#} P<0.001$, ${ }^{\dagger} P<0.0001$.

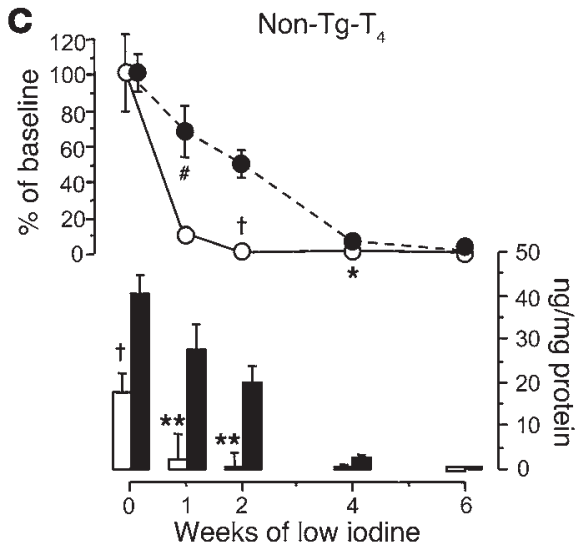

precipitation, prior to or following hydrolysis, showed that the increased content in thyroidal radioactivity in $\mathrm{Mct}$ - 8 -KO mice corresponded to a higher content of non-Tg- and Tg-TH.

Analogous results were obtained studying $\mathrm{T}_{4}$ secretion after acute stimulation with exogenous TSH. A single injection of TSH in mice pretreated with $\mathrm{L}_{-} \mathrm{T}_{3}$ elicited a lesser secretion of $\mathrm{T}_{4}$ from the thyroid glands of Mct8-KO as compared with WT mice. We excluded the possibility of reduced sensitivity of $M c t 8$-KO mice to $\mathrm{TSH}$. In fact, at baseline we found no differences in the expression of the TSH receptor gene, which mediates the effects of TSH (27), or other genes that are regulated by TSH, such as Nis $(28,29), \mathrm{Tg}(30$, $31)$, and Tpo $(30,32)$, and the enzymatic activity of D1, regulated also by cAMP (33). Except for the defect in the secretion, Mct8-KO mice did not present any features found in mice with defective thyroidal response to TSH (34-36). They had normal iodine uptake, $\mathrm{Tg}$ iodination, iodothyronine coupling, and proliferative response to TSH and to goitrogens.

Further support for the presence of defective TH secretion in mice lacking Mct 8 came from the observation that with the implementation of a low-iodine diet, their thyroidal Tg-TH and non$\mathrm{Tg}-\mathrm{TH}$ content decreased more slowly. Indeed, in the Mct8-KO mice the rate of decrease of Tg-TH content was lesser than in WT mice after 1 and 2 weeks of low-iodine diet. Thyroidal Tg- $\mathrm{T}_{4}$ and $\mathrm{Tg}_{\mathrm{T}} \mathrm{T}_{3}$ attained the same degree of reduction in WT and Mct8-KO mice only after 4 weeks of iodine deficiency, when both reached the same absolute amounts. For the non-Tg-TH content, the differences between the two genotypes persisted until 4 weeks. This latter finding shows that even when the stored hormone is virtually completely depleted (see the undetectable Tg-iodothyronines),
Mct8-KO mice continue to have, because of the defect in the secretion, higher non- $\mathrm{Tg}-\mathrm{TH}$ content than the WT mice. As a result of the slower thyroidal TH depletion, the Mct8-KO mice showed overall lesser decline in serum $\mathrm{T}_{4}$ level than WT mice, and, therefore, their serum TSH levels rose more slowly (see difference at 4 weeks of low-iodine diet, Figure 9, A and B).

The finding of an important defect in the TH secretion in Mct8$\mathrm{KO}$ mice suggested that Mct8 is an important TH transporter expressed in the mouse thyroid gland. To confirm this assumption, we measured the expression levels of Mct8 and the other known putative TH transporters in the thyroid glands of WT mice. Of the studied TH transporters, Mct 8 was the most abundantly expressed, followed by Mct10, with a mean mRNA level 14\% that of Mct 8 and Lat1, and Lat2 trailing at $0.9 \%$ and $0.5 \%$. Of these last 3 transporters, only Mct 10 has been reported to have a high affin-

Table 2

mRNA levels of TH transporters in WT mouse thyroid gland

$\begin{array}{lc}\text { TH transporter } & \text { Gene copies/ng total RNA } \\ \text { Ntcp } & <0.1 \\ \text { Oatp1a1 } & <0.1 \\ \text { Oatp1a4 } & <0.1 \\ \text { Oatp1b2 } & <0.1 \\ \text { Oatp1c1 } & <0.1 \\ \text { Oatp3a1 } & <8 \\ \text { Oatp4a1 } & <0.2 \\ \text { Oatp1a5 } & <2\end{array}$




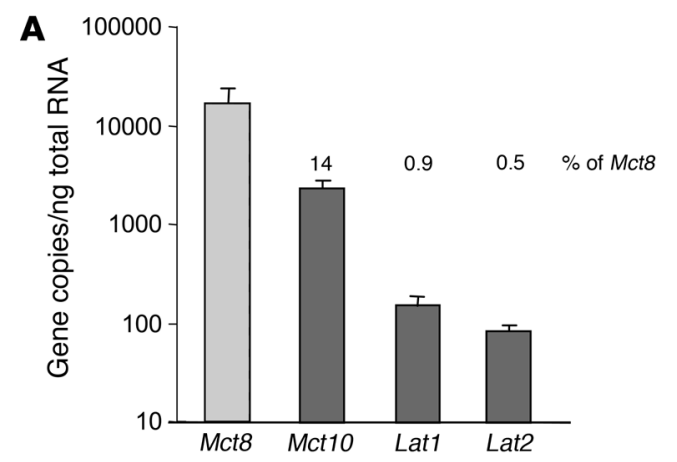

B

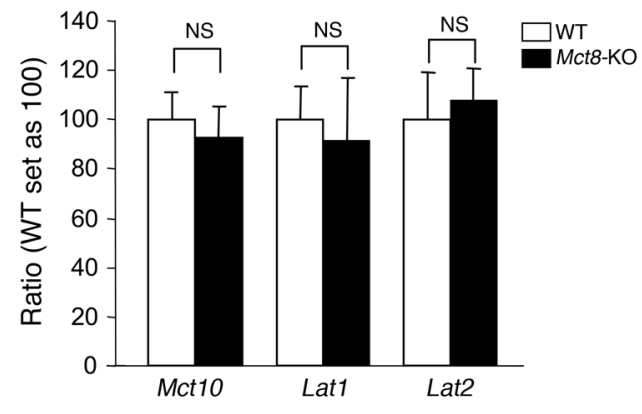

ity for iodothyronines and to be able to stimulate the efflux of $\mathrm{TH}$, though still less than Mct8 (37). The other $8 \mathrm{TH}$ transporters studied were undetectable in thyroid tissue. In addition, the lack of Mct8 was not compensated by an increase in the expression of the other transporters, such as Mct10, Lat1, and Lat2, that were equally expressed in thyroid glands of $M c t 8-\mathrm{KO}$ and WT mice.

In light of all the results presented herein, we can conclude that Mct8 is an important TH transporter involved in the secretion of TH from the mouse thyroid gland. This study is the first to our knowledge to demonstrate a molecular mechanism mediating $\mathrm{TH}$ secretion. In addition, it shows that the low serum $\mathrm{T}_{4}$ present in Mct8 deficiency is due not only to the consumptive effect caused by the increase in $5^{\prime}$ deiodination, but also to a defect of $\mathrm{TH}$ secretion from the thyroid gland. However, our results do not exclude the involvement of other known or not-yet-identified TH transporters in TH secretion.

Does MCT8 play the same role in human as in the mouse thyroid gland? A recent study reported that MCT8 is expressed in the human thyroid gland. Using qPCR, Nishimura and Naito (38) demonstrated that human MCT8 is expressed abundantly in the thyroid gland. In addition, similar to our results in mice, MCT10 mRNA in the human thyroid is $14.3 \%$ that of MCT8 (38). Since mice and humans deficient in MCT8 present the same thyroid phenotype, it is likely that they share the same pathogenic mechanisms, and, therefore, the molecular mechanism regulating TH secretion described in this study for mice could also exists in humans.

\section{Methods}

Experimental animals. Procedures carried out in mice and described below were approved by the University of Chicago Institutional Animal Care and Use Committee. Animals were housed in temperature- $\left(22 \pm 2{ }^{\circ} \mathrm{C}\right)$ and light-controlled (12-hour light/12-hour dark cycle; lights on at $7 \mathrm{am}$ ) conditions and had free access to food and water. Mct8-KO mice were generated as described previously (14). Unless specified otherwise, each experiment was carried out on different groups of 10- to 14-week-old

\section{Figure 11}

mRNA levels of Mct8 and the other TH transporters in mouse thyroid gland. (A) Transcript levels of Mct8 and other putative TH transporters were measured in the WT mouse thyroid gland by qPCR. Mct8 was the most abundantly expressed TH transporter. Bars represent the mean \pm SEM. The numbers above the bars show the amount of mRNA as percentage of that of Mct8. (B) mRNA levels of Mct10, Lat1, and Lat2 in the thyroid of WT and Mct8-KO mice. Values are expressed as mean \pm SEM.

male WT $\left(\mathrm{Mct}^{+/ y}\right)$ and $\mathrm{KO}\left(\mathrm{Mct}^{-/ y}\right)$ littermates derived from more than 10 backcrossings of heterozygous females $\left(\mathrm{Mct}^{-/+}\right)$with WT males $\left(\mathrm{Mct} \mathrm{8}^{+/ /}\right)$ of the C57BL/6J strain. The genotype was confirmed by PCR of tail DNA (38 cycles at $55^{\circ} \mathrm{C}$ annealing temperature) using the following primers: forward common: $5^{\prime}$-ACAACAAAAAGCCAAGCATT-3'; reverse WT specific: 5'-GAGAGCAGCGTAAGGACAAA-3'; reverse knockout specific: $5^{\prime}$-CTCCCAAGCCTGATTTCTAT- $3^{\prime}$. Using this procedure, the WT allele generated a 476-bp product and the null allele a 239-bp PCR product. All animals were humanely euthanized.

Suppression of endogenous TH production. The endogenous TH production was suppressed with low-iodine diet (Harlan Teklad Co.) and the addition of $0.02 \%$ of methimazole (Sigma-Aldrich) and $0.5 \%$ perchlorate (SigmaAldrich) in the drinking water $\left(\mathrm{LoI} / \mathrm{MMI} / \mathrm{ClO}_{4}\right)$. After 2 weeks, mice were divided into 3 groups of 8 ( 4 per genotype). One group was euthanized at this same time, while the other 2 were placed on regular diet and water and euthanized 1 and 3 days later, respectively.

Bovine TSH stimulation test. A single injection of $2 \mathrm{mU}$ of bovine TSH (Sigma-Aldrich) was given i.p. to mice pretreated for 4 days with $10 \mu \mathrm{g} / 100 \mathrm{~g}$ $\mathrm{BW} / \mathrm{d}$ of $\mathrm{L}-\mathrm{T}_{3}$ (Sigma-Aldrich). Blood was obtained before and 1.5, 3, and 4.5 hours after bovine TSH injection for the measurement of $\mathrm{T}_{4}$. The optimal TSH dose and time of blood sampling were established by dose and time course experiments carried out in WT mice (39). In these experiments, the peak value was reached at 3 hours (39).

Treatment with low-iodine diet. The low-iodine diet used (Harlan Teklad Co.) for this experiment is a modification of the Remington diet containing less than $0.05 \mathrm{mg} / \mathrm{kg}$ of iodine (or $<0.05 \mathrm{ppm}$ ).

Kinetic studies of hormone secretion from the thyroid gland using ${ }^{125} I$. As in the McKenzie assay, used in the past for determination of the long-acting thyroid stimulator (40), mice weighing 25-30 g (no significant difference between the genotypes) were depleted of iodine with a low-iodine diet (Harlan-Teklad) for 2 weeks and then given a single i.p. injection of $5 \mu \mathrm{Ci}$ carrier-free ${ }^{125} \mathrm{I}$ (PerkinElmer). The radioactivity was measured in serum samples $8,20,32,44,56$, and 72 hour, after the ${ }^{125}$ I injection. At the same time points, the radioactivity in the mice thyroid glands was also measured in vivo, using the small probe of the Navigator gamma positioning system (ABS Medical). The difference between counts over the thyroid and thorax was attributed to thyroidal ${ }^{125} \mathrm{I}$. The experiment was terminated 72 hours after the ${ }^{125}$ I injection. Mice were anesthetized and, after a blood sample was obtained for serum counting, were perfused with heparinated saline to remove blood from thyroid gland prior to harvesting and counting.

The amount of radioactivity in serum samples and in excised thyroid glands was measured in a gamma scintillation counter (Cobra II Auto-Gamma, Packard) and expressed as percentage of injected dose. These calculations were carried out by counting ${ }^{125}$ I standards under the same conditions. The serum ${ }^{125}$ I-labeled protein fraction representing labeled iodothyronines was measured in $50 \mu \mathrm{l}$ of serum precipitated with 10\% TCA (Fisher Scientific) and counted along with a standard in a gamma scintillation counter.

To measure the amount of radioactivity in thyroidal non- $\mathrm{Tg}$ - and $\mathrm{Tg}$ iodothyronines, we extracted thyroid glands with methanol- $\mathrm{CaCl}_{2}$ without or with hydrolysis, respectively (see below), and following the protocol 
Table 3

Oligonucleotide sequences used for the quantification of mRNAs by real-time PCR

\section{Primer sequence}

\begin{tabular}{|c|c|c|}
\hline Gene & Forward & Reverse \\
\hline Ttf1 & 5'-GGTGCTGGGACTGGGATGT-3' & 5'-TCAAGATGTCAGACACTGAGAACG-3' \\
\hline Tshr & 5'-TGTGTCTTCCACCAGCGTCA-3' & 5'-TGGTAGATGGGACCCCTCAA-3' \\
\hline Tpo & 5'-GCTGTGACCGAAGATGACCA-3' & 5'-GCGGAGGAGCGGTAGAAAG-3' \\
\hline $\operatorname{Tg}$ & 5'-GCCCACCATCTGTGGACTTC-3' & 5'-САТТССССТTТСАСАТСССА-3' \\
\hline Nis & 5'-GTGGGCCAGTTGCTCAATTC-3' & 5'-GTGCGTAGATCACGATGCCA-3' \\
\hline Dehal1 & 5'-ACACCGCCCCAGTTCTGAT-3' & 5'-ACCGTCACTAGCCCTGCATT-3' \\
\hline Mct8 & 5'-GTGCTCTTGGTGTGCATTGG-3' & 5'-CCGAAGTCCCGGCATAGG-3' \\
\hline Mct10 & 5'-GGCCGCATTGCTGACTATTTT-3' & 5'-CAATGGGCGCCATGATAGA-3' \\
\hline Lat1 & 5'-CTGCTGACACCTGTGCCATC-3' & 5'-GGCTTCTTGAATCGGAGCC-3' \\
\hline Lat2 & 5'-CCAGTGTGTTGGCCATGATC-3' & 5'-TGCAACCGTTACCCCATAGAA-3' \\
\hline Ntcp & 5'-CССTCTCTGTGGCTGTCACA-3' & 5'-TGGACGTTTTGGAATCCTGTT-3' \\
\hline Oatp1a1 & 5'-AAGAGCCTCTGCTGCAATCC-3' & 5'-AGGCATACTGGAGGCAAGCTAT-3' \\
\hline Oatp1a4 & 5'-ACCTCCAATATGCCTCGGATATT-3' & 5'-TTGTGTTGCAGTCAGCAAGGA-3' \\
\hline Oatp1b2 & 5'-CAGCAGTTTGGTCAGACAGCAT-3' & 5'-GGTCAAGGTTAGGCCAGCAA-3' \\
\hline Oatp1c1 & 5'-AATTCTAGTGTGGCCGGACTGA-3' & 5'-CAGCAAGACAAGCCGACACAT-3' \\
\hline Oatp3a1 & 5'-TCTGAGTGCGCCTTGATGC-3' & 5'-AGAGAATCAGCGCCAGGTTG-3' \\
\hline Oatp4a1 & 5'-ATCGGCAAAGATCCTTTGCC-3' & 5'-TA ACGAAGCAGGAGCCCTG-3' \\
\hline Oatp1a5 & 5'-GGTCCTTGCTGACTGCAACA-3' & 5'-CCTGATGACTGAATGCAGCTG-3' \\
\hline Pax8 & 5'-CAGCAGTGGTCCTCGAAAGC-3' & 5'-GGTTGCGTCCCAGAGGTGTA-3' \\
\hline$\beta$-actin & 5'-GGCCCAGAGCAAGAGAGGTA-3' & 5'-CTGGATGGCTACGTACATGGC-3' \\
\hline
\end{tabular}

Scientific) in PBS (pH 7.4). The fixed tissue was washed in PBS, then cryoprotected by equilibration with graded concentrations of sucrose $(10 \%, 20 \%$, and $30 \%)$ in PBS, embedded in Tissue Freezing Medium (Triangle Biomedical Sciences), and frozen in liquid nitrogen. Frozen sections $(8 \mu \mathrm{m})$ of thyroid glands were collected on Superfrost Plus slides (Fisher Scientific), air dried, and then stored at $-80^{\circ} \mathrm{C}$. For antibody labeling, sections were blocked with $5 \%$ BSA in PBS with $0.1 \%$ Tween 20 (Roche) for 1 hour and incubated overnight at $4{ }^{\circ} \mathrm{C}$ with Mct8 antibody (1:500). Sections were washed with PBS and incubated in 1:5,000 rabbit antimouse Mct 8 and $100 \mu \mathrm{g} / \mathrm{ml}$ biotinylated peanut agglutinin (PNA; Vector Laboratories), which labels the cell membrane. Goat anti-rabbit IgG conjugated to Alexa Fluor 555 and avidin-Alexa Fluor 488 (Molecular Probes) were used to detect anti-Mct8 and PNA binding, respectively. The buffer used for incubation with primary and secondary antibodies was $1 \%$ BSA and $0.1 \%$ Triton $\mathrm{X}-100$ (Roche) in PBS. Sections were washed and coverslips were mounted with Gelvatol. Both primary and secondary antibod-

described in refs. 41,42 . They were then precipitated with TCA after addition of carrier serum (see above).

Blood and tissue collection. Blood was obtained from the tail vein or by retro-orbital puncture with a heparinated micropipette. For tissue collection, mice were perfused with heparinated PBS through a needle placed in the left ventricle when the tissue was required for measurement of TH content. Animals were perfused with the fixative when tissues were collected for histology and immunohistochemistry.

Iodothyronines and TSH determinations in serum. Serum total $\mathrm{T}_{4}$ and $\mathrm{T}_{3}$ concentrations were measured by coated tube RIAs (Diagnostic Products) adapted for mouse using 25 and $50 \mu \mathrm{l}$ serum, respectively. TSH was measured in $50 \mu \mathrm{l}$ serum using a sensitive, heterologous, disequilibrium, double-antibody precipitation RIA (43).

$T g$-and non- $T g-T_{4}$ and $-T_{3}$ content in the thyroid gland. The entire thyroid gland was dissected from the surrounding tissues and homogenized in $150 \mu \mathrm{l}$ of $0.1 \mathrm{M}$ phosphate buffer, $\mathrm{pH}$ 7, containing $1 \mathrm{mM}$ EDTA and $4 \mathrm{mM}$ DTT. The homogenate was then divided into aliquots used for the measurement of total and non- $\mathrm{Tg}-\mathrm{T}_{4}$ and non- $\mathrm{Tg}-\mathrm{T}_{3}$ content, mRNAs, and iodothyronine deiodinase enzymatic activity. For measurement of thyroidal total $\mathrm{T}_{4}$ and $\mathrm{T}_{3}$ content, $10 \mu \mathrm{l}$ of thyroid homogenate was added to $60 \mu \mathrm{l}$ lysis buffer (50 mM Tris-HCl, pH 8, 100 mM EDTA [Fisher Scientific], $100 \mathrm{mM} \mathrm{NaCl}$, $1 \%$ SDS [Bio-Rad], $1 \mathrm{mM}$ propylthiouracil [Sigma-Aldrich]) followed by $2 \mu \mathrm{l}$ Proteinase $\mathrm{K}$ (Ambion). After hydrolysis for 2 hours at $37^{\circ} \mathrm{C}$, the iodothyronines were extracted with methanol- $\mathrm{CaCl}_{2}$, as previously described $(41,42) . T_{4}$ and $T_{3}$ content were measured by RIA. To measure the thyroidal content of non- $\mathrm{Tg}-\mathrm{T}_{4}$ and non- $\mathrm{Tg}-\mathrm{T}_{3}, 40 \mu \mathrm{l}$ of the thyroid homogenate was extracted without hydrolysis, and the procedure described above was followed. The Tg-TH was calculated by subtracting corresponding non-Tg-TH from total TH measured after hydrolysis. For both, total and non-Tg-TH, recovery was monitored by addition of labeled iodothyronines before tissue extraction, and the recovery rates ranged from $78 \%$ to $85 \%$.

Immunohistochemical analysis. Thyroid glands were removed from perfused animals (see above) and postfixed overnight in $4 \%$ paraformaldehyde (Fisher ies were diluted in $1 \%$ BSA in PBST, and phalloidin was diluted with PBS. Immunofluorescence labeling of tissue was visualized with a Zeiss LSM 510 confocal microscope (Zeiss Microscope Imaging Inc.). Images were exported in "tagged image file" format using LSM Image Browser software (version 3,5,0,376, Zeiss Microscope Imaging Inc.). Single optical sections are shown, and adjustments of images were made to brightness and contrast only. The Mct8 antibody used in these studies was generated to the carboxyl terminus of mouse Mct8 (DPNGELLPGSPTPEEPI) by Ian Simpson (Hershey Medical Center, Hershey, Pennsylvania, USA). The specificity of Mct8 antibody was demonstrated by the absence of labeling in tissue sections prepared from Mct8-KO mice and the presence of anti-Mct8 labeling in HEK293 cells overexpressing MCT8 (data not shown).

Immunoblot analysis. The entire thyroid gland was dissected from the surrounding tissues and homogenized in ice-cold lysis buffer $(25 \mathrm{mM}$ HEPES buffer, $\mathrm{pH} 7.4,150 \mathrm{mM} \mathrm{NaCl}, 5 \mathrm{mM} \mathrm{MgCl}$, $1 \%$ Triton X-100) containing protease inhibitors (Complete Mini, Roche) for 30 minutes on ice. Tissue homogenates were centrifuged at $14,000 \mathrm{~g}$ at $4^{\circ} \mathrm{C}$ for 30 minutes and the cleared lysates removed for protein determination and immunoblot analysis. Lysates were diluted in $2 \times$ LDS sample buffer (Invitrogen), and equal amounts of protein were run on $4 \%-12 \%$ NuPAGE Bis-Tris gels (Invitrogen), then transferred electrophoretically from gels to Immobilon-P membranes (Millipore). Membranes were incubated for 1 hour at room temperature in blocking buffer $(20 \mathrm{mM}$ Tris, $137 \mathrm{mM} \mathrm{NaCl}, \mathrm{pH}$ 7.5, 5\% dry skim milk), followed by 1 hour incubation with primary antibodies and 30 minutes incubation with HRP-conjugated secondary antibodies diluted 1:5,000. Blots were probed with antibodies to Mct8 and to $\beta$-actin (SigmaAldrich). Reactive bands were visualized with electrochemiluminescent Western blotting detection reagents (GE Healthcare Life Sciences).

Histological morphometry. Four randomly selected thyroid slides stained with H\&E from 2 mice of each group were used for morphometry by NIH ImageJ software (http://rsb.info.nih.gov/ij/). Fifty thyroid follicles were analyzed from each slide, and the following parameters were quan- 
tified, as previously described (34): colloid-containing area, whole follicle area, thyrocyte area (whole follicle area minus colloid area), number of visible nuclei, and average thyrocyte size (thyrocyte cell area divided by number of visible nuclei).

Measurement of specific $m R N A$ content in the thyroid gland by $q P C R$. Total RNA was extracted using phenol/guanidine isothiocyanate (TRIzol, Invitrogen), and $2 \mu \mathrm{g}$ total RNA was reverse transcribed using Superscript III RNase H Reverse Transcriptase Kit (Invitrogen) in the presence of $100 \mathrm{ng}$ random hexamers. Reactions for the quantification of mRNAs by real-time qPCR were performed in an ABI Prism 7000 Sequence Detection System (Applied Biosystems), using SYBR Green I (Bio-Rad) as detector dye. The oligonucleotide primers were designed to cross introns. Primers used for the qPCR of thyroid transcription factor 1 (Ttf1), TSH receptor (Tshr), Tpo, Tg, Nis, iodothyrosine deiodinase (Dehal1), Mct8, Mct10, Lat1, Lat2, and other TH transporter mRNAs are listed in Table 3 . The expression of genes was calculated relative to that in the WT mice and normalized for the Pax8 gene, using the $2^{-\triangle \triangle C T}$ method (44). These results were similar to those obtained using as internal control $\beta$-actin mRNA.

For absolute quantitative assays of TH transporters, a standard curve was generated after amplification of known amounts of specific templates for each transporter gene to calculate the number of mRNA copies in each sample.

Measurement of D1 enzymatic activity in thyroid gland. D1 enzymatic activity in thyroid gland was measured as described previously (45) with the following modifications: $20 \mu \mathrm{g}$ tissue homogenates in $100 \mu \mathrm{l}$ reaction mixture containing $0.1 \mathrm{M}$ phosphate buffer ( $\mathrm{pH}$ 7), $1 \mathrm{mM}$ EDTA, $10 \mathrm{mM}$ DTT, 100,000 cpm [125 I] $\mathrm{T}_{4}$ (PerkinElmer), and $1 \mu \mathrm{M}$ unlabeled $\mathrm{T}_{4}$ (Sigma-
Aldrich) were incubated at $37^{\circ} \mathrm{C}$ for 1 hour. The enzymatic activity was expressed in picomoles per hour and milligram of protein and was corrected for nonenzymatic deiodination observed in the tissue-free controls.

Statistics. All results are expressed as mean \pm SEM. Statistical analysis was performed using 2-tailed Student's $t$ test for unpaired observations (comparison of values obtained in WT and Mct8-KO mice) and ANOVA with Fisher's protected least significant differences (comparison among 3 or more groups). Logarithmic transformation of data was performed when SDs for different groups varied by more than 20 -fold and sometimes by 1,000-fold (see TSH). A $P$ value less than 0.05 was considered significant.

\section{Acknowledgments}

This work was supported in part by NIH grants 4R37-DK15070 and 2P60-DK020595 and the Esformes Endowment. Special thanks to go the Sherman family for their support.

Received for publication December 21, 2009, and accepted in revised form June 16, 2010.

Address correspondence to: Samuel Refetoff, University of Chicago, MC3090, 5841 South Maryland Avenue, Chicago, Illinois 60637, USA. Phone: 773.702.6939; Fax: 773.702.6940; E-mail: refetoff@uchicago.edu.

This work was presented at the 91st annual meeting of the Endocrine Society in Washington, DC, USA, on June 10-13, 2009.
1. Carrasco N. Iodide transport in the thyroid. Biochim Biophys Acta. 1993;1154(1):65-82.

2. Everett LA, et al. Pendred syndrome is caused by mutations in a putative sulphate transport gene (PDS). Nature Genet. 1997;17(4):411-422.

3. Taurog A. Thyroid peroxidase and thyroxine biosynthesis. Recent Prog Horm Res. 1970;26:189-247.

4. De Deken X, et al. Cloning of two human thyroid cDNAs encoding new members of the NADPH oxidase family. J Biol Chem. 2000;275(30):23227-23233.

5 . Friedrichs B, et al. Thyroid functions of mouse cathepsins B, K, and L. J Clin Invest. 2003;111(11):1733-1745.

6. Gnidehou $\mathrm{S}$, et al. Iodotyrosine dehalogenase 1 (DEHAL1) is a transmembrane protein involved in the recycling of iodide close to the thyroglobulin iodination site. FASEB J. 2004;18(13):1574-1576.

7. Ekins R. The free hormone hypothesis and measurement of free hormones. Clin Chem. 1992; 38(7):1289-1293

8. Abe T, Suzuki T, Unno M, Tokui T, Ito S. Thyroid hormone transporters: recent advances. Trends Endocrinol Metab. 2002;13(5):215-220.

9. Hennemann G, Docter R, Friesema EC, de Jong M, Krenning EP, Visser TJ. Plasma membrane transport of thyroid hormones and its role in thyroid hormone metabolism and bioavailability. Endocr Rev. 2001;22(4):451-476.

10. Friesema EC, Ganguly S, Abdalla A, Manning Fox JE, Halestrap AP, Visser TJ. Identification of monocarboxylate transporter 8 as a specific thyroid hormone transporter. J Biol Chem. 2003;278(41):40128-40135.

11. van der Deure WM, Peeters RP, Visser TJ. Molecular aspects of thyroid hormone transporters, including MCT8, MCT10, and OATPs, and the effects of genetic variation in these transporters. J Mol Endocrinol. 2010;44(1):1-11.

12. Dumitrescu AM, Liao XH, Best TB, Brockmann K, Refetoff S. A novel syndrome combining thyroid and neurological abnormalities is associated with mutations in a monocarboxylate transporter gene. Am J Hum Genet. 2004;74(1):168-175.

13. Friesema EC, et al. Association between mutations in a thyroid hormone transporter and severe
X-linked psychomotor retardation. Lancet. 2004; 364(9443):1435-1437.

14. Dumitrescu AM, Liao XH, Weiss RE, Millen K, Refetoff S. Tissue-specific thyroid hormone deprivation and excess in monocarboxylate transporter (mct) 8-deficient mice. Endocrinology. 2006; 147(9):4036-4043.

15. Trajkovic M, et al. Abnormal thyroid hormone metabolism in mice lacking the monocarboxylate transporter 8. J Clin Invest. 2007;117(3):627-635.

16. Heuer $\mathrm{H}$, et al. The monocarboxylate transporter 8 linked to human psychomotor retardation is highly expressed in thyroid hormone sensitive neuron populations. Endocrinology. 2005;146(4):1701-1706.

17. Di Cosmo C, Liao XH, Dumitrescu AM, Weiss RE, Refetoff S. A thyroid hormone analog with reduced dependence on the monocarboxylate transporter 8 for tissue transport. Endocrinology. 2009; 150(9):4450-4458.

18. Ceballos A, et al. Importance of monocarboxylate transporter 8 (Mct8) for the blood-brain barrier dependent availability of 3,5,3'-triiodo-l-thyronine (T3). Endocrinology. 2009;150(5):2491-2496.

19. Friesema EC, Kuiper GG, Jansen J, Visser TJ, Kester $\mathrm{MH}$. Thyroid hormone transport by the human monocarboxylate transporter 8 and its rate-limiting role in intracellular metabolism. Mol Endocrinol. 2006;20(11):2761-2772.

20. Obregon MJ, Escobar del Rey F, Morreale de Escobar G. The effects of iodine deficiency on thyroid hormone deiodination. Thyroid. 2005;15(8):917-929.

21. Pedraza PE, Obregon MJ, Escobar-Morreale HF, del Rey FE, de Escobar GM. Mechanisms of adaptation to iodine deficiency in rats: thyroid status is tissue specific. Its relevance for man. Endocrinology. 2006;147(5):2098-2108.

22. Dumont JE, Maenhaut C, Christophe D, Vassart G, Roger PP. Thyroid regulatory factors. In: DeGroot LJ, Jameson JL, eds. Endocrinology. Volume 2. Philadephia, Pennsylvania, USA: Elsevier, Mosby, Saunders; 2006:1837-1860.

23. Visser WE, Friesema EC, Jansen J, Visser TJ. Thyroid hormone transport in and out of cells. Trends Endo- crinol Metab. 2008;19(2):50-56.

24. Dumitrescu AM, Liao XH, Weiss RE, Refetoff S. High circulating T3 in Mct8 deficient mice is an age related postnatal event dependent on the ontogeny of deiodinases[OR52-2]. In: Program \& Abstracts, The Endocrine Society's 89th annual meeting. Toronto, Canada; 2007:145-146.

25. Schneider PB. Thyroidal iodine heterogeneity: "last come, first served" system of iodine turnover. Endocrinology. 1964;74:973-980.

26. Cortese F, Schneider AB, Salvatore G. Isopycnic centrifugation of thyroid iodoproteins: selectivity of endocytosis. Eur J Biochem. 1976;68(1):121-129.

27. Vassart G, Dumont JE. The thyrotropin receptor and the regulation of thyrocyte function and growth. Endocr Rev. 1992;13(3):596-611.

28. Kogai T, Endo T, Saito T, Miyazaki A, Kaaguchi A, Onaya T. Regulation by thyroid-stimulating hormone of sodium/iodide symporter gene expression and protein levels in FRTL-5 cells. Endocrinology. 1997;138(6):2227-2232.

29. Levy O, et al. Characterization of the thyroid $\mathrm{Na}^{+} / \mathrm{I}^{-}$ symporter with an anti-COOH terminus antibody. Proc Natl Acad Sci U S A. 1997;94(11):5568-5573.

30. Gerard CM, et al. Control of thyroperoxidase and thyroglobulin transcription by cAMP: evidence for distinct regulatory mechanisms. Mol Endocrinol. 1989;3(12):2110-2118.

31. Van Heuverswyn B, Streydio C, Brocas H, Refetoff S, Dumont J, Vassart G. Thyrotropin controls transcription of the thyroglobulin gene. Proc Natl Acad Sci US A. 1984;81(19):5941-5945.

32. Chazenbalk G, Magnusson RP, Rapoport B. Thyrotropin stimulation of cultured thyroid cells increases steady state levels of the messenger ribonucleic acid for thyroid peroxidase. Mol Endocrinol. 1987;1(12):913-917.

33. Pekary AE, Berg L, Santini F, Chopra I, Hershman JM. Cytokines modulate type I iodothyronine deiodinase mRNA levels and enzyme activity in FRTL-5 rat thyroid cells. Mol Cell Endocrinol. 1994; 101(1-2):R31-R35.

34. Kero J, et al. Thyrocyte-specific G(q)/G(11) defi- 
ciency impairs thyroid function and prevents goiter development. J Clin Invest. 2007;117(9):2399-2407.

35. Marians RC, Ng L, Blair HC, Unger P, Graves PN, Davies TF. Defining thyrotropin-dependent and -independent steps of thyroid hormone synthesis by using thyrotropin receptor-null mice. Proc Natl Acad Sci U S A. 2002;99(24):15776-15781.

36. Postiglione MP, et al. Role of the thyroid-stimulating hormone receptor signaling in development and differentiation of the thyroid gland. Proc Nat Acad Sci U S A. 2002;99(24):15462-15467.

37. Friesema EC, Jansen J, Jachtenberg JW, Visser WE, Kester $\mathrm{MH}$, Visser TJ. Effective cellular uptake and efflux of thyroid hormone by human monocarboxylate transporter 10. Mol Endocrinol. 2008;22(6):1357-1369.

38. Nishimura M, Naito S. Tissue-specific mRNA expression profiles of human solute carrier transporter superfamilies. Drug Metab Pharmacokinet. 2008;23(1):22-44.

39. Moeller LC, Kimura S, Kusakabe T, Liao XH, Van Sande J, Refetoff S. Hypothyroidism in thyroid transcription factor 1 haploinsufficiency is caused by reduced expression of the thyroid stimulating hormone receptor. Mol Endocrinol. 2003; 17(11):2295-2003.

40. McKenzie J. The bioassay of thyrotropin in serum. Endocrinology. 1958;63(3):372-382.

41. Morreale de Escobar G, Calvo R, Escobar del Rey F, Obregon MJ. Thyroid hormones in tissues from fetal and adult rats. Endocrinology. 1994;134(6):2410-2415.

42. Morreale de Escobar G, Pastor R, Obregon MJ, Escobar del Rey F. Effects of maternal hypothyroidism on the weight and thyroid hormone content of rat embryonic tissues, before and after onset of fetal thyroid function. Endocrinology. 1985;117(5):1890-1900.

43. Pohlenz J, Weiss RE, Cua K, Van Sande J, Refetoff S. Improved radioimmunoassay for measurement of mouse thyrotropin in serum: Strain differences in thyrotropin concentration and thyrotroph sensitivity to thyroid hormone. Thyroid. 1999;9(12):1265-1271.

44. Livak KJ, Schmittgen TD. Analysis of relative gene expression data using real-time quantitative PCR and the 2(-Delta Delta C(T)) Method. Methods. 2001;25(4):402-408.

45. Balzano S, Bergmann BM, Gilliland MA, Silva JE, Rechtschaffen A, Refetoff S. Effect of total sleep deprivation on 5 -deiodinase activity of rat brown adipose tissue. Endocrinology. 1990;127(2):882-890. 